\title{
Implementasi Pembelajaran Pendidikan Jasmani Adaptif bagi Siswa Tunarungu di SLB Negeri 2 Padang Melalui Penugasan Dosen di Sekolah
}

\author{
Johandri Taufan ${ }^{1}$, Resvi Fitri ${ }^{2}$, Rafmateti ${ }^{3}$ \\ ${ }^{1}$ Dosen Jurusan Pendidikan Luar Biasa, Universitas Negeri Padang, Indonesia \\ ${ }^{2}$ Guru Sekolah Luar Biasa Negeri 2 Padang, Indonesia \\ ${ }^{3}$ Kepala Sekolah Sekolah Luar Biasa Negeri 2 Padang \\ Email: johandri.taufan@fip.unp.ac.id
}

\section{INFORMASI ARTIKEL}

Terkirim 06 Oktober 2019

Revisi 20 Oktober 2019

Diterima 25 November 2019

\section{Kata kunci:}

Jasmani Adaptif, Tunarungu,

Penugasan Dosen di Sekolah, SLB

\begin{abstract}
ABSTRAK
Penugasan Dosen di Sekolah (PDS) merupakan strategi peningkatan kompetensi dosen LPTK yang dapat memberikan pengalaman nyata mengelola pembelajaran di sekolah. Pengalaman tersebut pada akhirnya akan diimplementasikan dalam pembelajaran di LPTK untuk menyiapkan guru di masa depan. Artikel ini ditulis untuk mendeskripsikan pelaksanaan PDS dalam implementasi pembelajaran pendidikan jasmani adaptif di SLB Negeri 2 Padang. Pendidikan jasmani adaptif merupakan pembelajaran pendidikan jasmani, olahraga dan kesehatan yang dalam kegiatan pembelajarannya telah dimodifikasi baik dari pelaksanaan kegiatan, rencana pembelajaran, kurikulum, permainan dan penilaian. Hasil dalam kegiatan pembelajaran pendidikan jasmani adaptif melalui program PDS ini, tampak dari pengembangan-pengembangan kegiatan jasmani yang dilakukan oleh guru, baik dari bentuk rencana kegiatan, alat dan pelaksanaan kegiatan.
\end{abstract}

\section{PENDAHULUAN}

Program Dosen ke Sekolah atau yang dikenal dengan PDS adalah sebuah program yang dirancang oleh pemerintah melalui Kementrian Riset, Teknologi dan Pendidikan Tinggi. PDS merupakan kegiatan yang dirancang untuk peningkatan kompetensi dosen yang dapat memberikan pengalaman nyata mengelola pembelajaran di sekolah. Pengalaman yang diperoleh tersebut pada akhirnya akan diimplementasikan dalam pembelajaran di LPTK untuk menyiapkan guru masa depan. Pengalaman berperan sebagai guru di sekolah dapat memberikan pengalaman nyata dan menghayati pembelajaran di sekolah. Dosen perlu menyesuaikan dengan berbagai hal yang biasa berlaku di sekolah.

Artikel ini ditulis untuk mendeskripsikan hasil dari implementasi kegiatan pembelajaran pendidikan jasmani adaptif bagi anak berkebutuhan khusus yaitu siswa tunarungu di SLB Negeri 2 Padang melalui Program Penugasan ke Sekolah. Pembelajaran pendidikan jasmani adaptif dipilih karena pada dasarnya di Sekolah Luar Biasa (SLB) terdapat anak berkebetuhan khusus yang memiliki hambatan dan kesulitan, baik secara fisik, mental, emosional dan intelektual.

Pendidikan jasmani adaptif sendiri merupakan pendidikan jasmani, olahraga dan kesehatan (PJOK) yang telah dimodifikasi, baik dari bentuk olahraganya, alat-alatnya, rancangan pembelajarannya, dan bahkan kurikulumnya. Adapun pendidikan jasmani pada hakikatnya adalah proses pendidikan yang memanfaatkan aktivitas fisik untuk menghasilkan perubahan holistik dalam kualitas individu, baik dalam hal fisik, mental, serta emosional. Pendidikan jasmani seharusnya memperlakukan anak sebagai sebuah kesatuan utuh, mahluk total, tidak hanya menganggap sebagai seseorang yang terpisah kualitas fisik dan mentalnya. Pada dasarnya pendidikan jasmani, dengan memanfaatkan alat gerak manusia, dapat membuat aspek mental dan moral pun ikut berkembang. Adanya hambatan dan gangguan yang dialamai oleh peserta didik berkebutuhan khusus atau yang dikenal dengan anak berkebutuhan khusus menjadikan mereka mengalami keterbatasan bahkan tidak mampu mengikuti beberapa kegiatan pembelajaran salah satunya adalah pembelajaran pendidikan jasmani, olahraga dan kesehatan. Sehingga dalam rangka mengaktualisasikan pemberian layanan pendidikan dengan kualitas yang sama pada semua peserta didik, dalam pendidikan jasmani untuk peserta didik berkebutuhan khusus perlu dilakukan penyesuaian (adaptasi).

Pendidikan jasmani adaptif merupakan pembinaan pendidikan jasmani bagi siswa yang memiliki kecacatan. Menurut (Hendrayana, 2007:7) menyatakan bahwa : Pendidikan jasmani adaptif adalah sebuah program yang bersifat 
individual yang meliputi fisik/jasmani, kebugaran gerak, pola dan keterampilan gerak dasar, keterampilan-keterampilan dalam aktivitas air, menari, permainan olahraga baik individu maupun beregu yang didesain bagi penyandang cacat.

Sama halnya dengan pendidikan jasmani yang dilakukan pada siswa normal lainnya, pendidikan jasmani adaptif disajikan untuk membantu siswa agar memahami mengapa manusia bergerak dan bagaimana cara melakukan gerakan secara aman, efisien, dan efektif. Siswa yang berkebutuhan khusus memiliki kemampuan gerak yang sangat terbatas dalam mengikuti pendidikan jasmani. Fakor penting yang harus diperhatikan dalam pembelajaran pendidikan jasmani adaptif adalah semua intruksi harus jelas dan isyarat-isyarat yang diberikan dapat dipahami dengan baik.

Pada pelaksanaanya, penerapan pembelajaran pendidikan jasmani adaptif bagi siswa berkebutuhan khusus masih memerlukan pengembangan dan modifikasi, baik dari segi kegiatannya maupun pengajarannya. SLB Negeri 2 Padang sendiri belum memiliki guru bidang studi pendidikan jasmani, olahraga dan kesehatan, sehingga dalam pelaksanaannya siswa-siswa berkebutuhan khusus dikembalikan kepada wali kelasnya. Hal ini merupakan permasalahan yang sering kali membuat wali kelas menjadi bingung karena mereka bukanlah guru yang berlatarbelakang pendidikan jasmani, olahraga dan kesehatan.

Melalui program penugasan dosen di sekolah yang diadakan oleh Universitas Negeri Padang di bawah naungan Kemenristikdikti maka permsalahan yang ditemukan dilapangan menjadi bagian penting dalam perbaikan kualitas pembelajaran. Sehingga pada kegiatan ini diadakan sebuah kerjasama dengan sekolah mitra yaitu SLB Negeri 2 Padang untuk melaksanakan pembelajaran pendidikan jasmani adaptif. Sehingga apa yang di implementasikan oleh dosen di sekolah dapat di terapkan oleh guru, baik wali kelas maupun guru mata pelajaran. Pada pelaksanaan pembelajaran pendidikan jasmani adaptif ini dosen menerapkan pembelajaran pendidikan jasmani adaptif bagi siswa tunarungu. Pada siswa yang mengalami gangguan pendengaran (tunarungu) proses komunikasi tidak lancar karena siswa tunarungu tidak mampu mendengar intruksi yang disampaikan oleh guru pendidikan jasmani. Menurut (Tarigan, 2008:30) ada dua kategori gangguan pendengaran, yaitu : Pertama disebut tuli berarti adanya kerusakan pada alat pendengaran yang cukup berat sehingga tidak bisa menerima informasi bahasa termasuk memprosesnya, dan yang kedua adalah sulit mendengar berarti adanya kerusakan pada alat pendengaran yang sifatnya bisa tetap dan tidak tetap, namun tidak sama dengan tuli. Untuk memperlancar komunikasi dalam pembelajaran pendidikan jasmani dengan siswa, para guru pendidikan jasmani dapat melakukannya dengan cara melaui isyarat-isyarat melalui tangan. Disamping itu juga dapat dilakukan dengan cara menempelkan materi pelajaran di papan pengumuman, misalnya konsep mengenai kualitas gerak, kesadaran tubuh dan ruang, dan lebih baik lagi bila disertai gambar-gambar yang menarik perhatian siswa. Guru pendidikan jasmani harus memaksimalkan sumber informasi, diantaranya dengan memanfaatkan media visual.

\section{METODE}

\section{A. Jenis Penelitian}

Jenis penelitian yang digunakan dalam penelitian ini adalah pendekatan deskriptif jenis kualitatif. Menurut Andi Prastowo (2011: 203) metode penelitian deskriptif merupakan metode penelitian yang berusaha mengungkap fakta suatu kejadian, objek, aktivitas, proses, dan manusia secara "apa adanya" pada waktu sekarang atau jangka waktu yang memungkinkan dalam ingatan responden.

\section{B. Waktu dan tempat penelitian}

Penelitian ini dilaksanakan di Sekolah Luar Biasa Negeri 2 Padang pada tanggal 25 Juli - 26 September 2019. Kegiatan dilakukan selama 8 (delapan) kali pertemuan setiap hari Kamis.

\section{Subyek Penelitian}

Subyek penelitian adalah subyek yang ingin dituju untuk diteliti oleh peneliti. Subyek penelitian dalam penelitian ini meliputi anak tunarungu yang berada di kelas XI dan satu wali kelas yang menjadi guru penjas.

D. Instrumen dan Teknik Analisis Data

Instrumen yang digunakan untuk mengumpulkan data pada penelitian ini adalah panduan observasi, pedoman wawancara dan pedoman dokumentasi.

\section{E. Teknik Analisis}

Data yang diperoleh melalui observasi, wawancara, dan dokumentasi kemudian dianalisis. Sama dengan pendekatan jenis deskriptif yang digunakan dalam penelitian ini, teknik analisis datanya juga bersifat deskriptif kualitatif. Aktivitas dalam analisis data yaitu data reduction, data display, dan conclusion drawing (verification). Miles dan Huberman dalam (Sugiyono, 2006: 337) mengemukakan bahwa aktivitas dalam analisis data kualitatif dilakukan secara interatif dan berlangsung terus menerus sampai tuntas, sehingga datanya sudah jenuh 


\section{HASIL PENELITIAN \\ Deskripsi Perencanaan Pembelajaran Penjas Adaptif}

Dasar penyusunan tujuan adalah Aspek yang mendasari guru pendidikan jasmani dalam merancang tujuan yang hendak dicapai, diantaranya kondisi anak, kebutuhan anak, kemampuan anak, program yang sedang dijalankan anak, dan silabus. Indikator keberhasilan adalah anak tunarungu mampu melakukan gerakan tidak berpindah tempat, kemampuan bergerak berpindah tempat, gerakan keseimbangan, gerakan dengan kekuatan anggota gerak, gerakan dengan kelentukan anggota gerak, gerakan kelincahan, kecepatan dan kelenturan. Dalam perencanaannya pembelajaran jasmani adaptif di sekolah, biasanya guru menempatkan anak sesuai dengan bidang olahraga yang dirasa cocok dan dapat dikuasai anak. Beberapa kegiatan olahraga yang diterapkan di sekolah diantaranya adalah permainan bola kaki, badminton, boucce dan beberapa kegiatan olahraga lainnya. Pada pelaksanaan pembelajaran yang dilakukan peneliti bersama guru adalah mengkolaborasikan beberapa keterampilan, baik itu keterampilan kognitif, afektif dan psikomotor.

Perencanaan pembelajaran pendidikan jasmani adaptif melalui penugasan dosen ke sekolah ini dilakukan selama 8 kali pertemuan. Sebelum melaksanakan kegiatan, peneliti terlebih dahulu melakukan diskusi bersama dengan guru, karena guru lebih memahami bagaimana kondisi peserta didik. Penyusunan rencana program pembelajaranpun disesuaikan dengan kondisi peserta didik dan sarana prasarana yang berada di sekolah. Selain itu penentuan jenis kegiatan olahragapun penting, agar dapat ketepatan pemberian layanan pada peserta didik sesuai dengan kemampuan yang dimilikinya. Perencanaan pembelajaran pendidikan jasmani adaptif melalui penugasan dosen ke sekolah ini dilakukan selama 8 kali pertemuan.

\section{Kompetensi Guru}

Pembelajaran pendidikan jasmani adaptif yang dilakukan di Sekolah Luar Biasa perlu dikembangkan, baik dari segi pelaksanaan pembelajarannya sampai dengan kemampuan guru dibidang pendidikan jasmani ini. Beberapa Sekolah Luar Biasa memang tidak memiliki guru khusus yang mengajarkan pendidikan jasmani adaptif, sehingga pembelajaran jasmani atau olahraga lebih sering dilaksanakan oleh guru kelas masing-masing. Dalam hal ini SLB N 2 Padang sendiri tidak memiliki guru mata pelajaran jasmani atau olahraga, sehingga kegiatan olahraga biasanya dilakukan bersamaan dengan guru-guru kelas dan mata pelajaran yang lain.

Pemahaman guru terhadap kemampuan peserta didik tunarungu sangat baik, guru memahami hambatan dan potensi yang dapat dikembangkan pada peserta didik tunarungu yang berada dikelasnya. Permasalahan yang ditemui adalah kurangnya pemahaman guru dalam melakukan komunikasi dengan peserta didik tunarungu.

\section{Kurikulum}

Mata pelajaran pendidikan jasmani olahraga dan kesehatan merupakan mata pelajaran khusus yang ada di Sekolah Luar Biasa. Modifikasi pembelajaran pendidikan jasmani olahraga dan kesehatan ini adalah menjadi pendidikan jasmani adaptif. Dimana pembelajaran jasmani adaptif ini hampir sama dengan pembelajaran olahraga pada umumnya, hanya saja dari segi pelaksanaannya berbeda karena harus disesuaikan dengan kemampuan peserta didik. Kurikulum yang digunakan pada kegiatan pembelajaran jasmani adaptif ini adalah Kurikulum K13. Untuk panduannya disesuaikan dengan buku guru yang telah disediakan oleh Kementerian Pendidikan dan Kebudayaan. Pelaksanaan pembelajaran jasmani adaptif ini memodifikasi kurikulum yang telah ada, sehingga tujuannya tidak lari dari panduan yang telah dibuat oleh Kemendikbud.

Bersama guru, peneliti memilih beberapa kegiatan olahraga yang dapat dimodifikasi bagi peserta didik tunarungu sehingga dapat lebih mengembangakan kemampuan peserta didik, dan peserta didik dapat lebih antusias dalam pembelajaran pendidikan jasmani adaptif. Materi yang diberikan meliputi latihan kecepatan, keseimbangan, kerjasama dan sebagainnya.

\section{Sarana dan Prasarana}

Sekolah Luar Biasa Negeri 2 Padang merupakan sekolah yang memiliki sarana dan prasarana cukup lengkap. Termasuk sarana dan prasarana untuk kegiatan olahraga. Kegiatan yang dilakukan pada pembelajaran pendidikan jasmani adaptif inipun dapat berjalan dengan lancar karena ketersediaan peralatan yang ada di sekolah cukup memadai. Sarana dan prasarana yang ada di sekolah juga dapat digunakan oleh peserta didik tunarungu sehingga peserta didik dapat menggunakan dan memainkannya.

\section{PEMBAHASAN}

Pembelajaran pada dasarnya merupakan proses aktivitas yang dilakukan secara tertata dan teratur, berjalan secara logis dan sistematis mengikuti aturan-aturan yang telah disepakati sebelumnya. Setiap kegiatan pembelajaran bukan merupakan proyeksi keinginan dari guru secara sebelah pihak, akan tetapi merupakan perwujudan dari berbagai keinginan yang dikemas dalam suatu kurikulum. Menurut Oemar Hamalik (2009:50), hal-hal yang harus diperhatikan dalam membuat rencana pembelajaran yaitu:

1. Rencana yang dibuat harus disesuaikan dengan tersedianya sumber-sumber

2. Organisasi pembelajaran harus senantiasa memperhatikan situasi dan kondisi masyarakat sekolah 
3. Guru selaku pengelola pembelajaran harus melaksanakan tugas dan fungsinya dengan penuh tanggung jawab.

Berdasarkan penjelasan diatas dapat dikatakan bahwa perencanaan pembelajaran sangat penting, seperti halnya perencanaan pembelajaran pada pembelajaran pendidikan jasmani adaptif. Perencanaan yang baik akan menghasilkan pembelajaran yang baik karena telah disesuaikan dengan rencana yang telah dibuat. Pada perencanan pelaksanaan pembelajaran pendidikan jasmani adaptif ini sendiri telah didiskusikan bersama dengan guru kelas, sehingga tujuan yang akan di capai dapat terlaksana dengan baik.

Perlunya pengembangan dan modifikasi pada perencanaan pembelajaran sangatlah penting, terutama pada kurikulum yang diadposi dari pembelajaran olahraga yang bersifat umum. Dengan adanya modifikasi pada pembelajaran pendidikan jasmani adaptif ini, peneliti dan guru dapat mengetahui kemampuan dan hambatan yang dimiliki oleh peserta didik tunarungu. Sehingga pada pelaksanaannya semua peserta didik tunarungu dapat ikut serta dalam kegiatan olahraga, dan semua peserta didik dapat mengikuti pembelajaran dengan baik.

Adanya sarana dan perasarana juga merupakan faktor yang sangat penting dalam tercapainya tujuan pembelajaran. Kelengkapan sarana dan prasarana dapat menjadi point yang cukup membantu dalam pelaksanaan pembelajaran. Pada mata pelajaran jasmani adaptif, alat-alat dan media sangatlah dibutuhkan dalam kegiatan. Pada kegiatan pembelajaran pendidikan jasmani adaptif, peneliti bersama guru menggunakan alat dan media yang telah ada di sekolah, sehingga pembelajaran jasmani adaptif ini dapat berjalan dengan lancar dan baik. Penggunaan alat dan media yang tepat dan sesuai dapat menjadikan kemampuan peserta didik lebih berkembang dengan baik.

Kompetensi guru dalam kegiatan pembelajaran pendidikan jasmani adaptif cukup baik. Terlihat guru memahami dan cepat menguasai apa yang dicontohkan oleh peneliti. Pada pelaksanaanya guru juga melakukan hal yang sama dengan peneliti yaitu sama memberikan contoh dan instruksi kepada peserta didik. Hal ini dilakukan agar kemampuan guru dapat lebih berkembangan sehingga guru dapat memberikan pembelajaran sesuai dengan komptensi yang dimiliki.

\section{KESIMPULAN}

Program Penugasan Dosen ke Sekolah merupakan program yang sangat baik, karena dengan adanya program ini dapat memberikan dampak positif baik bagi LPTK maupun bagi Sekolah Laboratorium dan atau Sekolah mitra. Pada pelaksanaanya dosen harus mampu memberikan contoh bagi calon guru dalam melaksanakan tugas keprofesiannya. Dengan adanya program PDS di Sekolah Luar Biasa Negeri 2 Padang dapat memberikan pemahaman dan pengembangan kemampuan guru dalam pembelajaran jasmani adaptif. Keterbatasan guru mata pelajaran pendidikan jasmani olahraga dan kesehatan membuat guru kelas merangkap menjadi guru mata pelajaran pendidikan jasmani olahraga dan kesehatan ini.

Melalui program PDS ini guru merasa terbantu, karena selama ini guru berfikir bahwasanya untuk pembelajaran olahraga bagi peserta didik berekebutuhan khusus cukup sulit. Dengan adanya program PDS ini, guru memahami bagaimana cara menyusun perencanaan pembelajaran sampai memodifikasi kegiatan olahraga dan alat-alat serta media yang digunakan khususnya bagi peserta didik tunarungu.

\section{DAFTAR PUSTAKA}

Andi, Prastowo. 2011. Memahami Metode-Metode Penelitian. Yogyakarta: Ar-ruz Media.

Beltasar Tarigan. 2000. Penjas Adaptif. Depdikbud. Direktorat Jenderal Pendidikan Dasar dan Menengah Bagian Proyek Direktorat Jendral Pembelajaran dan Kemahasiswaan. 2019. Panduan Program Penugasan Dosen di Sekolah (PDS), Ristekdikti.

Mulyasa. 2011. Menjadi Guru Profesional. Bandung: PT. Remaja Rosdakarya

Oemar Hamalik. 2009. Perencanaan Pengajaran Berdasarkan Pendekatan Sistem, Jakarta: PT Bumi Aksara.

Penataran Guru SLTP Setara D-III . 2002. Pendidikan Jasmani Adaptif. Bandung. FPOK UPI

Sri Widati dan Murtadlo. 2007. Pendidikan Jasmani dan Olahraga Adaptif. Jakarta: Depdiknas

Sugiyono. 2006. Metode Penelitian Pendidikan. Bandung. Alfabeta

Taufan, J., Ardisal, A., Damri, D., \& Arise, A. (2018). Pelaksanaan Pembelajaran Pendidikan Jasmani Adaptif bagi Anak dengan Hambatan Fisik dan Motorik. Jurnal Pendidikan Kebutuhan Khusus, 2(2), 19-24. 